from the Wenlock of Dudley, is taken as the type of a new genus Arcanopora.

The authors then remarked upon the characters on which the classification of the Polyzoa is founded, drawn from the study of the recent forms, and stated that throughout the Cainozoic and Mesozoic series no Polyzoa are known which cannot be referred to the recognized groups. Many Palæozoic forms are in a different case. The orifices seen on the surface are not, in many instances, the mouths of the cells, but those of what the authors call vestibules, beneath which the true cell-mouth is concealed. For these types they propose to found a new suborder under the name of CRYPTostomata, and characterized by having the zoœcia subtubular, or, in section, slightly angular, and the orifice surrounded by a vestibule or otherwise concealed. The families referred to this group are the Ceramoporidæ, Ptilodictyidæ, and Areanoporidæ.

\title{
MISCELLANEOUS.
}

Notes on the Luminosity of the Sea, taken on the West Coast of Norway from September 1881 to April 1882. By W. E. KocH, B.A., F.G.S.

I TROST the following notes may be of interest to naturalists, although I fear there is nothing new about them.

During my travels I was much struck by the almost constant luminosity of the waters: but I also noticed great variations in its intensity; sometimes it was quite as brilliant as I have ever seen it in southern climes, at others much fainter. It struck me that some of the flashes of light emitted by certain forms resembled the steelblue spark of an electric machine; hence I was led to try certain experiments with magnetized needles in buckets of water. The results obtained were decidedly disappointing; but nevertheless I feel sure that a great deal of the so-called phosphorescence is due to animal electricity, and I hope some one more competent and better fitted out than myself may undertake this line of research. Another fact which seems to fall in with this idea is that during thundery weather and displays of the aurora borealis the luminosity was most intense.

The highest temperature registered at night at the surface-water was $45^{\circ} \mathrm{F}$., the lowest $32^{\circ} \mathrm{F}$; ; and on both occasions the luminosity was equally brilliant.

The small light-emitting animals were of the usual types (Hydromedusce, Medusce, Ctenophora, \&c.); but many were embryonic forms quite unknown to me.

To quote from my diary :-

"September 14, 1881. Weather cold and windy (west wind). Waters crowded with medusoid forms; and all the way from Stavanger to the Lysefjord (15 English miles) the luminosity was most marked.

"September 29, 1881. East wind, fine and cold. Waters extraordinarily clear, so that forms of life could be easily distinguished 
in twelve fathoms of water. Luminosity was great, but not so intense as when a grey cloudiness, due to myriads of tiny creatures, tinges the fjord waters. This cloudiness is probably due to migration, and always precedes the arrival of herring-shoals; it is most marked in spring and autumn, and usually occurs with a westerly wind.

"All through November the luminosity was great, but especially so on the 23rd, when we had hail and lightning during the day and the aurora at night. The average temperature of surface-water during this month was $42^{\circ} \mathrm{F}$.

"On December 16 a violent east gale was blowing. Temperature of air about freezing-point, and surface-water $38^{\circ}$ to $40^{\circ} \mathrm{F}$. The whole fjord was streaked with fire; and the shore-line seemed a seething mass of flame. Some forms emitted disks of light which appeared to be 3 inches across.

"December 23, 1881. Thermometer $26^{\circ} \mathrm{F}$. in air, and $37^{\circ} \mathrm{F}$. in water. Splendid display of aurora, and sea gloriously luminous."

On December 27 I left Stavanger for Bergen; and at 5 A.M. the luminosity of the sea was wonderful, pillars of flame, disks and stars of fire tumbling one over another in the wake of the vessel; some emitted a yellow and others a white phosphorescent lingering light; but many gave forth steel-blue flashes exactly like eleetric sparks.

After spending a week examining the fine natural-history museum in Bergen, I returned to Stavanger on January 3rd, 1882, and the sea was luminous as usual. Constant luminosity during January and February.

In March I went to Haugesund to see the herring-fishery, and I found the waters grey with life and very luminous. I then went on into the Hardangerfjord; and as we crashed through the ice at Norheimsund, I noticed that it seemed to emit light on fracture. I had read somewhere that this was supposed to be due to electricity; so I got up some buckets of ice and water: eliminating the ice, I found the remaining water perfectly luminous, and I noticed that the steel-blue flash seemed to predominate. Here, then, was the explanation; but as I had not a microscope of sufficient power with me, I could not carry out my researches. As these creatures live quite well in water at freezing-point, possibly they may be even included in ice, and make long journeys without injury.

At Odde I noticed the same phenomenon, the ice being 3 inches thick.

I left Stavanger for Hull in April, and it was worthy of remark that the waters along the Norwegian coast were luminous; yet as we steamed westward the luminosity gradually diminished; hence I think that certain currents carry these animals northward along the coast and into the fjords.

In conclusion, I may sum up as follows :-

(a) That the luminosity of sea-water occurs all the year round; even when ice is present.

$(\beta)$ That it is greater during electrical atmospheric disturbances, and is partly caused by electricity.

$(\gamma)$ That it is also well marked during the migrations of fishes, Ann. \& Mag. N. Hist. Ser. 5. Vol. x. 
and may have an important bearing on their food and migrations.

( $\delta$ ) It appears to be at its maximum in spring and autumn, when the waters swarm with embryonic forms.

\section{On the Priority of Euplœa Castelnaui of Felder over Euplœa}

$$
\text { phœbus. By W. L. Distant. }
$$

Under the above heading, in the last issue of this magazine (ante, p. 73), Mr. Butler has expressed himself dissatisfied that in my 'Rhopalocera Malayana' I have used Felder's name for a species of Euploea in preference to one proposed by himself.

My reason for this arrangement was simply that Felder's publication bore date 1865, whilst Butler's description was published in 1866.

I was aware that Mr. Butler had preferred and published a charge that Felder's publication was antedated, and also that an explanation had been given by the Felders that the work could be obtained with uncoloured plates at their date of publication, though the coloured copies were not ready at that time. This statement I at least felt bound to accept; and I was under the impression that, from Mr. Butler having since published 1865 as the date of Felder's descriptions of Euploea, he had seen his way to withdraw from so serious a charge.

That accusation amounts, in the first instance, to one of literary mendacity, and, secondly, of publishing a designedly false statement in support of the same. This I cannot credit; and therefore I could not write my 'Rhopalocera Malayana' as though I did. It is only natural for Mr. Butler to regret the loss of some of his specific names; but he must pardon me for saying that I think he is illadvised in again making so serious a charge against the reputation of a lepidopterist who, though no longer here to reply, has still left a memory among friends and colleagues which, so far as I can learn, leaves no room for stain.

If, however, I write with pleasure that I accept both Felder's original date and subsequent explanation, it is with regret that I find an inclination on the part of my friend $\mathrm{Mr}$. Butler to think that in so doing I have in some way accused him of " a childish form of egotism." I am also sorry to have to notice the statement (probably in haste) made by Mr. Butler that, when I wrote that he had subsequently used Felder's date, I was "well aware" that in so doing he " had taken the date from the titlepage, either failing for the time being to recall the fact of its inaccuracy, or inserting it between inverted commas" to show his disbelief in it. I was aware of nothing of the kind when I wrote my first part, which was in proof when I mentioned my views to him. I was then told that the dates were either in inverted commas or had been altered by the Secretary of the Linnean Society. I found on reference that the inverted commas were non-existent; and I could not, when writing my part, first make a charge against the Felders on the authority of Butler, and then explain away his apparent withdrawal of the same by a somewhat invidious reference to the Secretary of the Linnean Society. 


\section{$2 \mathrm{BHL}$ Biodiversity Heritage Library}

Koch, W E. 1882. "Notes on the Luminosity of the Sea, taken on the West Coast of Norway from September 1881 to April 1882." The Annals and magazine of natural history; zoology, botany, and geology 10, 176-178. https://doi.org/10.1080/00222938209459689.

View This Item Online: $\underline{\text { https://www.biodiversitylibrary.org/item/94495 }}$ DOI: https://doi.org/10.1080/00222938209459689

Permalink: https://www.biodiversitylibrary.org/partpdf/68184

\section{Holding Institution}

Harvard University, Museum of Comparative Zoology, Ernst Mayr Library

\section{Sponsored by}

Harvard University, Museum of Comparative Zoology, Ernst Mayr Library

\section{Copyright \& Reuse}

Copyright Status: Public domain. The BHL considers that this work is no longer under copyright protection.

This document was created from content at the Biodiversity Heritage Library, the world's largest open access digital library for biodiversity literature and archives. Visit BHL at https://www.biodiversitylibrary.org. 